\title{
Investigating the Motivating Factors of Youths-Students Interest to Become Entrepreneurs: A Case of Anambra State, Nigeria
}

\author{
Simon Nnaemeka Ajah \\ Martin of Tours School of Management and Economics, Assumption University, Thailand. \\ Email:sajah@au.edu
}

\begin{abstract}
This study explored the factors that motivates the youth's interest (intention) to become entrepreneurs by incorporating the personality attributes from the "Theory of planned behavior" and environmental factors, with some selected "control variables" (experience, gender, and age). A multivariate statistical technique was used to test the relationship between the variables using "Structural Equation Modeling" AMOS Package version 23. A sample of 400 students from Chukwuemeka Odumegwu Ojukwu university in Anambra State, Nigeria was used to analyze the data. The results of the study indicated that attitude, self-efficacy, and subjective norms have a statistically significant effects on student's entrepreneurial interest. The findings also indicated that entrepreneurial education has an impact on students' attitude but has no obvious effect on intention. Apart from government support policy which was found to have statistical negative effect on intention, other external barriers have no effect on attitude and intention. Understanding these factors is important to make recommendations to the government and other relevant stakeholders to promote youths' entrepreneurship in Nigeria. The importance of entrepreneurship is not only vital for economic growth but also for long term sustainable development. Through the vital information gained from investigating these motivating factors of youth's interest to engage in entrepreneurship, the government and other important stakeholders can formulate effective policies to improve macroeconomic conditions to encourage university students to become entrepreneurs.
\end{abstract}

Keywords: Attitude, Entrepreneurship, Education, Intention, Self-efficacy, Subjective norms, Sustainable development.

JEL Classification: J08; J2 1; M13; Q01

\section{Introduction}

Among Nigeria's youths (students), entrepreneurship is a necessity rather than an alternative career choice. Essentially, the reason is not because of a favorable macroeconomic environmental conditions nor supportive government public policies but because of their personality attributes, entrepreneurial experience and knowledge acquired through education, training, apprenticeship, and networking among others are important factors that motivates youths' interest to become entrepreneurs. Moreover, Lopez, Alvarez, Martins, Perez, and RománnCalderón (2021) posited that entrepreneurial education creates an avenue for networking, business opportunity identification and self-confidence. Although the personality characteristics and entrepreneurial education are considered as vital in entrepreneurship development, government policy support creating a conducive macroeconomic environment and or windows of opportunity for new venture creation is imperative in the generation of entrepreneurial intention. Therefore, understanding students' individual personality attribute and windows of opportunity or barrier as motivating factors for entrepreneurial intention is crucial for sustainable development in Nigeria. This is more imperative to explore given the fact that there is high poverty and unemployment rates (33.3\%) in Nigeria particularly among the youths $(53.4 \%)^{1}$. Therefore, to tackle this problem, an effective entrepreneurship policy can help to reduce unemployment rate and for sustainable economic growth.

\subsection{Problem Statement}

The problem discussed in this study are two folds: economic and sustainable development. Firstly, from the economic perspective, among the many functions of government is the provision of public goods and services, which include but not limited to the promotion of economic growth, employment opportunities, and development etc. These functions might differ from country to country because, some countries perform better in administering those functions than the others. In the case of this study, Nigeria is ranked $161^{2}$ at Human Development Index (HDI) in 2020 and around 40\% (83 million) Nigerians live in poverty ${ }^{3}$ and $33 \%$ are currently unemployed. This indicator is unacceptable by any standard and detrimental to the country overall economic growth and development. So, the Nigerian government (development administrators) must re-orient itself by formulating and implementing effective

${ }^{1}$ https://tradingeconomics.com/nigeria/indicators (Accessed on January 17, 2022)

2 http://hdr.undp.org/en/data (Accessed on January 17, 2022)

${ }^{3}$ www.nigerianstat.gov.ng (Accessed on January 17, 2022) 
economic policies to mitigate this calamity. It is important to note that previous attempts directed towards encouraging entrepreneurial activities in Nigerian failed due to poor policy implementation and poor infrastructure, couple with an overbearing red-tap (Oghojafor, Kuye, Sulaimon, \& Okonji, 2009). Besides, lack of economic improvement and opportunity leads to high unemployment rate which hinders sustainable development (Rashid, 2019).

Secondly, from the sustainable development perspective, to achieve the "United Nations Sustainable Development Goals" (SGDs), empowering the youths through entrepreneurial education which will equipped and support the ambitious of youths to venture into new business is vital according to Economic and Affairs (2018) report. The importance of entrepreneurship is crucial for "sustainable development", according to Apostolopoulos, AlDajani, Holt, Jones, and Newbery (2018) entrepreneurship empowers youths and creates an avenue for financial inclusion among many others. According to Rashid (2019) entrepreneurship has a direct impact on SDG1 "poverty alleviation” and SDG8 “economic development \& unemployment reduction”. Furthermore, Baumol, Litan, Schramm, and Strom (2011) emphasized on the importance of empowering the youths and building human capital through entrepreneurial training to improve youths entrepreneurship skills and entrepreneurial activities. However, despite these facts and emphasis on the importance of entrepreneurship, the situation is different in Nigeria. As mentioned earlier, the situation of the human capital development in Nigeria is nothing to reckon with. Additionally, the macroeconomic system has less opportunities, lack of encouragement and lack of support from government and other institutions as posited by Igwe, Adebayo, Olakanmi, Ogbonna, and Aina (2013) and this puts a strain on achieving sustainable development in the country.

Although the government have mandated that entrepreneurial education to be compulsory in all the tertiary institutions in Nigeria to foster the growth of the human resource capital and self-reliance capability among the youth, it is far from fetched to becoming a reality. On that note, the policy in Nigeria "states that the government will provide affordable quality education for all Nigerians, the universal basic education and mass adult literacy programs will be pursued in earnest and the government will create incentives to expand access to information and communications technology which will facilitate leap-frogging to short-circuit the longer span of development" However, it is important to note that there is a huge distinction between policy pronouncement and policy implementation, the policy pronouncement in Nigeria is indeed different from the actions and implementations. According to Alemu (2019), a combination of both state and federal policies are required to promote and support entrepreneurship in Nigeria. It is an urgent call for the entire stakeholders as the issue of low human capital development and unemployment is at all-time high among the youths. This is alarming so; a reoriented youth's entrepreneurship empowerment policy is needed to remedy the situation in the country. Therefore, this study focuses on the personality motivating factors which includes (attitude towards behavior and subjective norms from TPB and self-efficacy) and the windows of opportunity (mandatory entrepreneurship education programmed, government policy support or environmental barrier) for undergraduate students of tertiary institutions in Anambra State, Nigeria to examine their impact on entrepreneurial intention. This research will reignite the entrepreneurial consciousness among Nigerian youths who fear that new initiatives may fail like others of its kind in the past.

Despite recent advancements in the personality motivating factors in predicting entrepreneurial intention, little research connects the entrepreneurial education, personality, and other external factors with sustainable development in the literature, so, this study will contribute in this area to enhance the knowledge of entrepreneurship intention. This paper is structured as follows, part two presents the entrepreneurship role in economic growth and "sustainable development" in Anambra State, Nigeria. Part three presents the literature review. Part four depicts methodology of the research. Part five shows the findings. The last part is the discussion, research implications and conclusion.

\subsection{Entrepreneurship Role in Economic Growth and Sustainable Development in Nigeria}

Entrepreneurship activities have been the engine of a nation's long-term economic growth (Ajah, 2019; Schumpeter, 2017). "Entrepreneurship is a function of innovation" which is critical in economic growth and sustainable development according to Schumpeter (2017). Youths (students) entrepreneurial activities are relatively strong in Nigeria regardless of their academic background because, lack of job opportunities have left them with few other options for income and survival. There has been a growing interest among scholars regarding the concept of entrepreneurship and sustainable economic development (Acs, Szerb, \& Autio, 2017) the role of entrepreneurship training and the role of government policy impact on youths interest to become entrepreneurs (Karimi, Biemans, Lans, Chizari, \& Mulder, 2016). Governments globally are recognizing entrepreneurship "not only as a key mechanism for enhancing economic development, particularly in regions where entrepreneurial activity was once vibrant and is now lagging but also as a good solution because, it provides a relatively non-controversial way to increase the proverbial pie, creating jobs and enhancing per capita income growth" (Shane, 2007). Hence, "entrepreneurs need access to resources and markets to succeed, and this is where national policies play a vital role" (Kressel \& Lento, 2012). The Nigerian government through "mandatory entrepreneurial education" in tertiary institution is trying to create opportunities and to improve the human capital for a more sustainable economic inclusiveness, growth, and development however, the effectiveness of those policies is not materializing effectively.

According to Abdullahi, Renukappa, Suresh, and Oloke (2021) Nigeria is the largest economy in African continent and the economy is still in the growth process so, encouraging entrepreneurs is vital. Couple of reason are involved, firstly, for inclusive growth, factually, many Nigerians are not directly benefiting in the economic growth presently which denotes that the UN sustainable development goals are far from fetched. Therefore, for inclusiveness growth and sustainable development, the government of Nigeria needs to encourage and support entrepreneurship especially among the youths wondering around the streets of every corner of the country. This will rekindle their sense of belongings thus, developing interest in becoming potential businesspeople soon and helping in the process of nation building, economic growth, and development. Secondly, entrepreneurship is very important in Nigeria as an emerging economy. Government needs to diversify the economy away from heavy reliance on crude oil export to a manufacturing economy, therefore, it is essential to create a conducive macroeconomic environment that promotes 
entrepreneurship by providing funds and other necessary tools as a business incubator to empower the youths. Additionally, the tertiary institution in Nigeria should be equipped and supported for entrepreneurship training and education. It is a saying that "better teach someone how to catch a fish so that when he or she gets hungry, they can fend for themselves”. Steve Job simply puts to the younger generation to "stay hungry. Stay foolish” (Jobs, 2009).

\subsection{Entrepreneurship in Nigeria and Anambra State Context}

Nigeria is a low middle income ${ }^{5}$, mixed economy and an emerging market. The country is expanding in financial, services, communications \& technology, and entertainment sectors ${ }^{6}$. Nigeria is ranked 27 th in the world in terms of GDP of 436.3 billion US dollars 7 . But Nigerian business environment is distorted by bureaucracy (red tapes) and inconsistent enforcement of commercial regulations. In other words, the policy development and implementation by the development administrators (Government Agencies) are not working effectively and needed to be re-oriented to facilitate national development. Nigeria has maintained its impressive growth over the past decade, and a key regional player in West Africa. Nigeria accounts for about "half of West Africa's population with approximately 206.1 million people" 7 and one of the largest populations of youths in the world. The country has an abundance of human and natural resources, and the largest oil exporter in the continent ${ }^{8}$. Apart from petroleum product, Nigeria has other natural resources like "natural gas, tin, iron ore, coal, limestone, niobium, lead, zinc, and arable land”. The "oil and gas sector accounts for about 10 per cent of gross domestic product (GDP), and petroleum export revenue represents around 86 per cent of total exports revenue" 9 . Although Nigeria economy is growing, poor infrastructure particularly in the power sector and other macroeconomic conditions poses a challenge. Nigeria's economic growth is hampered by inadequate power supply ${ }^{10}$, and these issues might dissuade youths' interest in entrepreneurship in the country. To create a supportive environment for entrepreneurship activities and sustainable growth in the "non-oil sector", the government and its agencies need to create a window of opportunity for youth interest in entrepreneurship in Nigeria.

\section{Literature Review, Theoretical Background, and Hypotheses Development}

Lawler and Joseph (2012) stated that, "an entrepreneur wears a multiple hat of an innovator, creativity head, leader, change maker, manager". The authors defined entrepreneurs as someone who recognizes and captures business opportunities to make profits. Individuals go into new venture to be independent or need for achievement etc. Scholars have adopted different theories like "Theory of planned behavior" (TPB) and "Need for Achievement Theory” to explore entrepreneurial intention (Ajzen, 2002; Barry, 1998). This study integrated TPB with other variables from the literature to examine students' intention to develop interest in becoming entrepreneurs in Anambra State, Nigeria.

\subsection{Entrepreneurial Intention}

According to Hai (2021), "intention refers to a course of action or plan that an actor considers necessary and thus intends to undertake to accomplish a certain behavior". Intentionality builds interest which is fundamental to the process of entrepreneurship because, entrepreneurship is always intentional (Krueger Jr, Reilly, \& Carsrud, 2000). "Intention is defined as a state of mind directing someone's attention to act on something" according to Vesalainen and Pihkala (1999). An interest to embark on new business is a targeted behavior and also a planned meditated action (Krueger Jr et al., 2000). It is the process of digging deep for information for the purpose of getting the necessary tools and ideas of the new venture intention. "Intention is defined as a motivational factor and willingness of a person to engage in certain behavior” (Ajzen, Fishbein, Lohmann, \& Albarracín, 2018).

\subsection{Attitude Towards Behavior on Entrepreneurial Intention}

Attitude is a "perceived level of positive and negative impressions toward acting on the particular behavior" according to Ajzen et al. (2018). It is a predisposition response in a steadily favorable or unfavorable way with respect to a given object (Ajzen, 2011). Furthermore, Shaver (2003) defined "attitude towards specific forms of behavior as the degree to which a person has a favorable or unfavorable evaluation of the behavior in question". Previous studies have found relationship between these variable, for instance, Solesvik (2013) studied the "employment choice and intentions among Norwegian students" and found that attitude toward behavior has a positive strong relationship with entrepreneurial intention. Additionally, Lopez et al. (2021) found a statistical relationship between attitude and intention to become an entrepreneur. Thus, the first hypothesis was formulated as follows:

H1. Attitude has a positive relationship with intention/interest become an entrepreneur

\subsection{Self-Efficacy on Entrepreneurial Intention}

Barbosa, Gerhardt, and Kickul (2007) defined self-efficacy “as an individual's belief in one's capability to organize and execute the course of action required to produce given attainments". Moreover, Gist (1987) defined self-efficacy "as ones belief in his or her own ability to perform a task and in their personal ability to effectively use their skill to achieve certain results" (Bandura, 1977). Aforementioned, studies like Zhao, Seibert, and Hills (2005) found that a persons' self-efficacy influences his or her entrepreneurial intention. Additionally, Liu, Lin, Zhao, and Zhao (2019) found that self-efficacy significantly influence entrepreneurial attitude and entrepreneurial intention. Moreover, Garaika, Margahana, and Negara (2019) also found a statistical significant relationship between self-efficacy and intention. Hence, $\mathrm{H} 2$ was devised:

H2. Self-efficacy has a positive relationship with intention/interest become an entrepreneur.

\footnotetext{
5 "https://www.ilae.org/files/dmfile/World-Bank-list-of-economies-2020_09-1.pdf (Accessed on January 17, 2022)"

6 "http://www.nigeria-consulate-frankfurt.de/English/Business/Economy/economy.html (Accessed on January 17, "2022)

7 "https://www.afdb.org/en/countries/west-africa/nigeria (Accessed on January 17, 2022)"

8 "https://www.worldbank.org/en/country/nigeria/overview\#1 (Accessed on January 17, 2022)"

9 "https://www.opec.org/opec_web/en/about_us/167.htm (Accessed on January 17, 2022)"

9 "https://www.opec.org/opec_web/en/about_us/167.htm (Accessed on January 17,
10 "https://www.usaid.gov/nigeria/economic-growth (Accessed on January 17, 2022)"
} 


\subsection{Subjective Norms on Entrepreneurial Intention}

According to Padilla-Angulo (2019), "subjective norm denotes how group of important people can influence the entrepreneurial intention of an individual". Moreover, Ajzen (2011) stated that "subjective norm is the perceived social pressure to engage or not to engage in behavior". Furthermore, García-Rodríguez, Gil-Soto, Ruiz-Rosa, and Sene (2015) noted that, "subjective norm is an individual's perception of some reference groups which may or may not approve of the behavior toward self-employment".

Regarding the relationship, previous literature like Martins and Perez (2020) posited that subjective norms exert positive support in self-employment and interest to become entrepreneur. Additionally, Li, Wu, and Wu (2008) indicated that the expectancy of families and other key persons have significant influence on the career choices of university students. However, Lopez et al. (2021) found a negative influence of subjective norms on intention, this indicated that the findings on this relationship are not sufficiently consistent (Fellnhofer \& Mueller, 2018). Therefore, H3 was devised:

H3. Subjective norm has a positive relationship with intention/interest become an entrepreneur.

\subsection{Entrepreneurial Education on Attitude and Entrepreneurial Intention}

Lawler and Joseph (2012) stated that perceived educational support refers to a supportive university environment. "Entrepreneurial education may affect student's entrepreneurial behavior positively" as indicated by Hynes and Richardson (2007).

Additionally, Drucker (2014) stated that entrepreneurship is learned through educational training. In confirmation to that, Kuratko (2016) posited that the individuals personality traits and abilities as well as their skills required to become entrepreneurs can be acquired through education and training. Previous studies have found relationship among these variables, for example, Liu et al. (2019) found that an extensive entrepreneurial education significantly stimulate entrepreneurial intention among university students. However, Vohora, Wright, and Lockett (2004) and Miranda, Chamorro-Mera, Rubio, and Pérez-Mayo (2017) stated that entrepreneurial education cannot predict entrepreneurial intention. Consequently, $\mathrm{H} 4$ \& $\mathrm{H} 5$ was devised:

H4. Entrepreneurial education has a significant impact on attitude towards behavior.

H5. Entrepreneurial education has significant impact on intention/interest become an entrepreneur.

\subsection{Government Policy Support or Environmental Barrier on Attitude and Entrepreneurial Intention}

Environmental support refers to a supportive macro environmental conditions and government policy support (Lüthje \& Franke, 2003). According to Ebitu, Glory, and Alfred (2016), inadequate funds, unstable power supply and inaccessible road networks among others impedes economic development and lack of youths interest in entrepreneurship in Nigeria. Moreover, the authors argued that "there is lack of government support policy and that the financial institutions both public and commercial are not readily giving credit/loans to startup companies" in Nigeria (ibid).

To that effect, Ebitu et al. (2016) noted that the government should create a thriving business environment by providing support system that motivate youths to engage in the process of entrepreneurship for long term economic growth and sustainable development. Besides, Kristiansen and Indarti (2004) posited that capital accessibility is one of the success criteria for entrepreneurship. According to Petrin (1994), "behind every success of entrepreneurship, there is always some sort of institutional government support". Individual entrepreneurial initiatives go along with enabling macroeconomic environmental policies that supports the ingenuities. The creation of such macro environment starts with the foundation policies for macroeconomic stability hence, policies and programs that are designed to motive and channel entrepreneurial talent towards new venture creation are needed to spur intention.

That means, "policies to increase the supply of entrepreneurs, policies developing the market for other inputs into successful entrepreneurship, policies for increasing the effectiveness of entrepreneurs and policies for increasing demand for entrepreneurship can significantly speed up entrepreneurial activities at the national, regional and community levels" Petrin (1994). The absence of these effective polices will create environmental barrier. Notably, "environmental barrier is one of the biggest factors that hinders youth's interest to open a new business. The barriers may relate to lack finance (no funding), raw materials, marketing, power, labor, technical or qualified consultancy and guidance or service support" according to Latha and Murthy (2009). Literatures like Lüthje and Franke (2003) found that perceived entrepreneurship related support or barrier influences students intention to become entrepreneurs. So, H6, H7, H8 \& H9 was devised:

H6. Government policy support has a positive relationship with attitude towards behavior.

H7. Government policy support has a positive relationship with intention/interest become an entrepreneur.

H8. Environmental barrier has a negative relationship with attitude towards behavior.

H9. Environmental barrier has a negative relationship with intention/interest become an entrepreneur.

\subsection{The Control Variables}

Multiple factors influence student's interest to become entrepreneurs. Apart from the theory, age and gender can influence intention according to Do Paço, Ferreira, Raposo, Rodrigues, and Dinis (2015); as well as entrepreneurial experience (Zhang, Duysters, \& Cloodt, 2014).

According to Vohora et al. (2004) "entrepreneurs who get the education they needed can identify new opportunities for commercial applications". In support of that, Landry, Amara, and Rherrad (2006) postulated that the more experience an individual has, the more the probability that he or she can detect the right business opportunities to exploit for new business.

Therefore, this study has included age, gender, and entrepreneurial experience as control variables to investigate students' intention/interest to become entrepreneurs. Figure 1 illustrates the relationships between the independent, control, and the dependent variables of the study. 


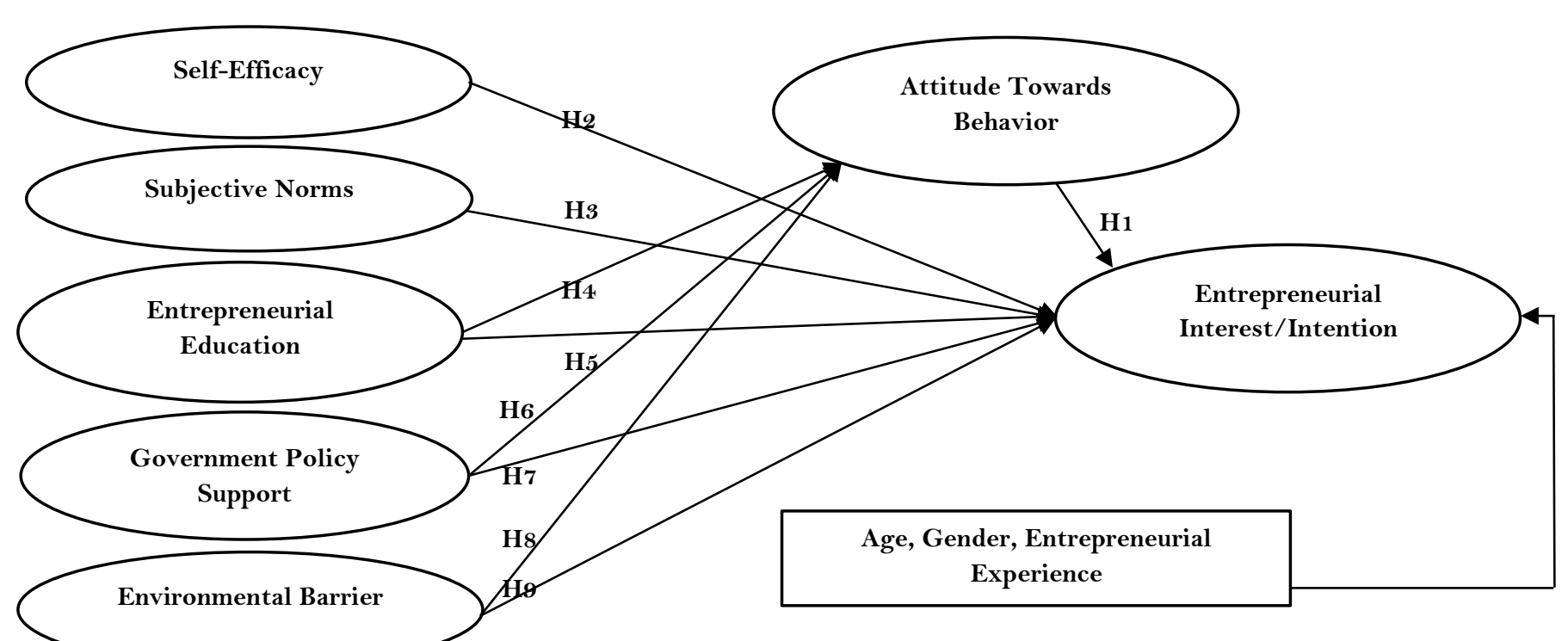

Figure 1. Conceptual framework.

\section{Method}

\subsection{Design, Target Population and Pilot Testing}

According to Bell, Bryman, and Harley (2018), "a research strategy is the overall coordination of how the research is conducted either as a quantitative or a qualitative strategy". This research adopted a quantitative methodology to investigate the factors influencing the youth's interest to become entrepreneurs in Anambra State, Nigeria. This is a case study of Chukwuemeka Odumegwu Ojukwu university students in Anambra State, Nigeria. The target population consisted of $12,500^{11}$ students. For pilot testing, 50 respondent's samples were used test about the timing and how difficult it was to understand the questions and adjustments were made from their feedback before the research instruments was finalized. 450 responses were gathered from online survey (electronic: google form), however, only 400 were used after removing the outliers using Mahalanobis distance Mahalanobis (1936). There were no missing data in the dataset because, the respondents cannot submit the questionnaire if any data was not completed. The questionnaire has eight parts which includes the demographic profile, the dependent variable intention, and the independent variables: attitude, self-efficacy, subjective norm, entrepreneurial education, government policy support and environmental barriers measurements. The questionnaire consisted of 31 items that sought to measure the constructs. All the indicators were adopted from previous studies. Students were asked to identify their opinion on each item of 5 -point Likert scale ranged from " $1=$ strongly disagree to $5=$ strongly agree".

Table 1. The list of indicators of factors.

\begin{tabular}{l|l|l|l}
\hline Factors & \multicolumn{1}{|c}{ Used Indicators } & Dropped Indicators & Sources \\
\hline Intention & ENT4, ENT5, ENT6 & ENT1, ENT2, ENT3 & Lopez et al. (2021) \\
\hline Attitude & ATB3, ATB4, ATB5 & ATB1, ATB2, & Lopez et al. (2021) \\
\hline Self-Efficacy & SE1, SE2, SE3 & -- & Chen, Gully, and Eden (2001) \\
\hline Subjective Norm & SBN1, SBN2, SBN3 & --- & Solesvik (2013) \\
\hline $\begin{array}{l}\text { Entrepreneurial } \\
\text { Education }\end{array}$ & EE2, EE3, EE4, EE5 & EE1 & $\begin{array}{l}\text { Fragoso, Rocha-Junior, and Xavier (2020); } \\
\text { Lopez et al. (2021) }\end{array}$ \\
\hline $\begin{array}{l}\text { Govt. Policy } \\
\text { Support }\end{array}$ & $\begin{array}{l}\text { GPS1, GPS2, GPS3, } \\
\text { GPS4 }\end{array}$ & -- & $\begin{array}{l}\text { Schwarz, Wdowiak, Almer-Jarz, and } \\
\text { Breitenecker (2009a) }\end{array}$ \\
\hline $\begin{array}{l}\text { Environmental } \\
\text { Barrier }\end{array}$ & $\begin{array}{l}\text { ENBR1, ENBR2, } \\
\text { ENBR3, ENBR4 }\end{array}$ & -- & Schwarz et al. (2009a) \\
\hline
\end{tabular}

\subsection{Sample and Procedure}

According to McDonald, Gan, Fraser, Oke, and Anderson (2015) "sampling procedure is the process of selecting a set of individuals able to represent the whole population from the targeted population that the proponent wished study". This can be done through "probability or non-probability" sampling technique (Saunders, Lewis, \& Thornhill, 2016). To determine the "sample size" of this research, a reference based on previous research with a similar topic was adopted. According to Israel (1992) a sample size can be determined using a sample size of a similar study to the one that the proponent plan to study. To that effect, Garaika et al. (2019) studied "self-efficacy, self-personality and self-confidence on entrepreneurial intention: study on young enterprises" using 200 respondents. Moreover, Koksal, Namal, Vehid, and Yurtsever (2005) distributed 300 questionnaires in their study titled "factors affect entrepreneurial intention of university students". Additionally, Solesvik (2013) dispersed 321 response survey questions in their study titled "entrepreneurial motivations and intentions: investigating the role of education major". Furthermore, Karimi et al. (2016) investigated "the impact of entrepreneurship education: a study of Iranian students' entrepreneurial intentions and opportunity identification” and the authors collected a sample of 205 participants. Therefore, 400 simple size was drawn from Chukwuemeka Odumegwu Ojukwu university students in Anambra State, Nigeria using connivence sampling technique.

\subsection{Validity-Test and Reliability-Test}

The validity and reliability were tested to confirm the research measurements. The factor analysis was examined through maximum likelihood. The validity and reliability were established with confirmatory factor 
loadings (CFA), the average variance extracted (AVE), and the composite reliability (CR). According to Hair, Hult, Ringle, and Sarstedt (2021) the CFA should not be below 0.5, the AVE should not be below 0.5 and CR should be above 0.7. Moreover, the "discriminant validity" was examined by "comparing the square root of average variance extracted (AVE) with the correlation of itself to other variables". "The square root of AVE of the construct has to be greater than any correlation that is involved". The constructs that were above 0.5 in CFA was used for further analysis as it suggests that the scale convergent validity was adequate nonetheless, the construct below 0.5 in CFA was removed (see Table $1 \&$ Table 4 and Figure 2) for list the of indicators adopted. Meanwhile, the discriminant validity was also confirmed with "AVE above the MSV (maximum shared variance)" statistics for all the factors (Hair et al., 2021). Additionally, the sample adequacy was again confirmed with the "Kaiser-Meyer-Olkin" (KMO), and the result (0.786) statistics was above the acceptable threshold of (0.6) for all factors measured (see Table 2). Table 3 depicted the AVE and CR and the overall model goodness of fit for the model is displayed in Table 5 adopted from Meyers, Gamst, and Guarino (2016). AMOS-23 Graphic Software was used to test the hypotheses. The data were fitted to the model, and there was no validity or reliability concerns in the construct.

Table 2. KMO and bartlett's test.

\begin{tabular}{|c|c|c|}
\hline \multicolumn{2}{|c|}{ "Kaiser-Meyer-Olkin Measure of Sampling Adequacy" } & 0.786 \\
\hline \multirow[t]{3}{*}{ "Bartlett's Test of Sphericity" } & Approx. Chi-Square & 8332.173 \\
\hline & $\mathrm{df}$ & 465 \\
\hline & Sig. & 0.000 \\
\hline
\end{tabular}

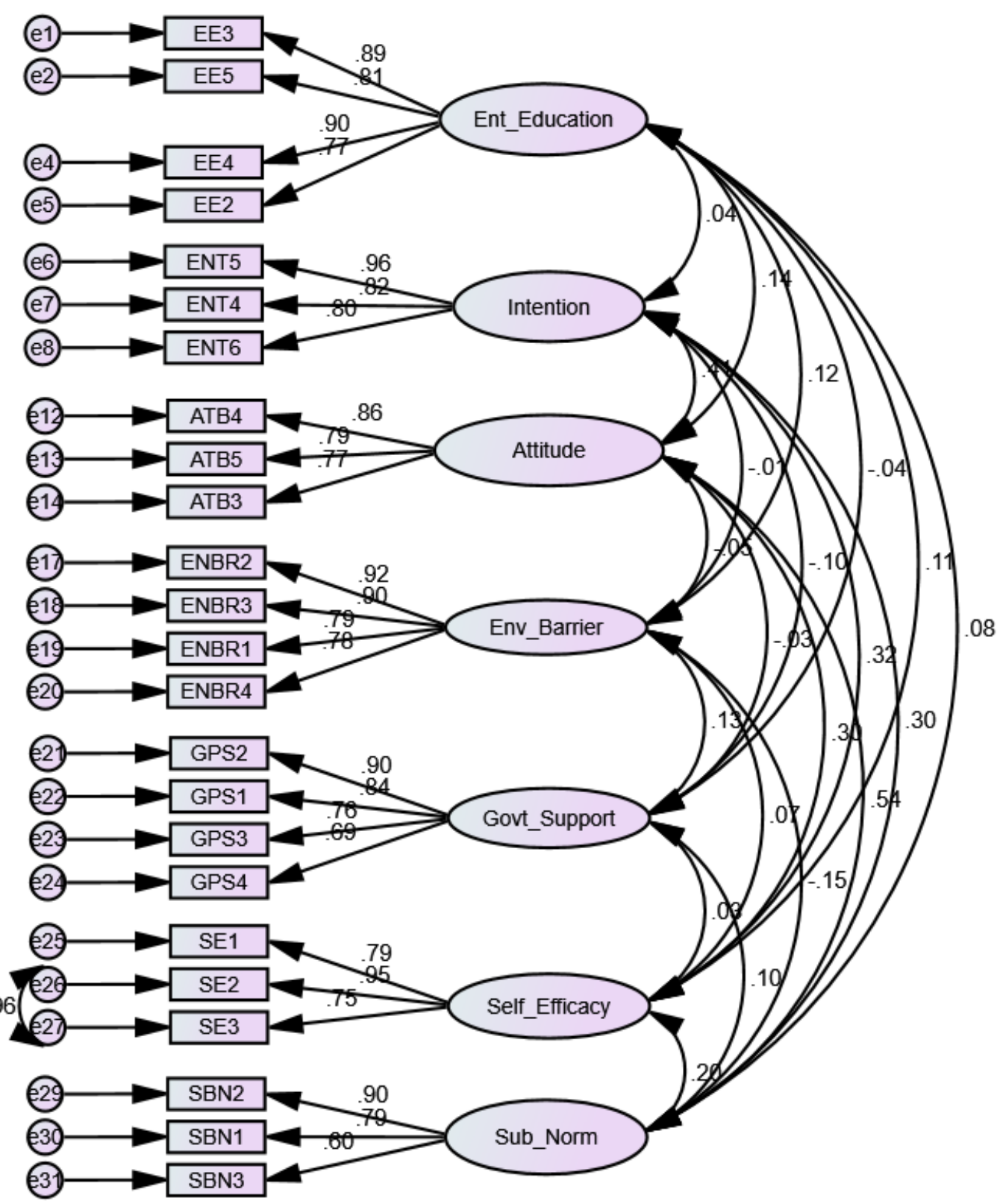

Figure 2. CFA "Extracted from Amos-23".

Note: Goodness-of-fit statistics: Relative chi-square $=2.980 ; \mathrm{GFI}=0.903, \mathrm{AGFI}=0.883, \mathrm{CFI}=0.906, \quad \mathrm{IFI}=0.907$, PCFI $=0.736, \mathrm{PNFI}=0.704, \mathrm{RMSEA}=0.070$. 
Table 3. Validity and reliability test.

\begin{tabular}{|c|c|c|c|c|c|c|c|c|c|c|c|}
\hline & $\mathbf{C R}$ & AVE & MSV & $\operatorname{Max} R(H)$ & Ent-Education & Attitude & Env-Barrier & Govt-Support & Intention & Self-Efficacy & Subjective Norm \\
\hline Entrepreneurial Education & 0.908 & 0.712 & 0.02 & 0.92 & 0.844 & & & & & & \\
\hline Attitude & 0.85 & 0.655 & 0.295 & 0.859 & $0.142 *$ & 0.809 & & & & & \\
\hline Environmental Barrier & 0.911 & 0.721 & 0.024 & 0.928 & $0.118^{*}$ & -0.052 & 0.849 & & & & \\
\hline Government Support & 0.877 & 0.643 & 0.016 & 0.898 & -0.038 & -0.028 & $0.128 *$ & 0.802 & & & \\
\hline Intention & 0.898 & 0.746 & 0.17 & 0.942 & 0.039 & $0.412^{* * * *}$ & -0.007 & $-0.104 \%$ & 0.864 & & \\
\hline Self-Efficacy & 0.841 & 0.642 & 0.099 & 0.878 & $0.139^{*}$ & $0.272 * * *$ & $0.103+$ & 0.039 & $0.315^{* * * *}$ & 0.801 & \\
\hline Subjective Norm & 0.813 & 0.598 & 0.295 & 0.863 & 0.083 & $0.543 * * *$ & $-0.154 * *$ & $0.099+$ & $0.304 * * *$ & $0.189 * *$ & 0.773 \\
\hline
\end{tabular}

Note: Significance of Correlations: $\uparrow \mathrm{p}<0.100,{ }^{*} \mathrm{p}<0.050,{ }^{* *} \mathrm{p}<0.010,{ }^{* * *} \mathrm{p}<0.001$.

Source: Hu and Bentler (1999): "Cutoff Criteria for Fit Indexes in Covariance Structure Analysis: Conventional Criteria Versus "New Alternatives SEM. Extracted from Gaskin and Lim (2016) Master Validity Tool, AMOS Plugin". 
Table 4. CFA: Extracted from (SPSS-23) pattern matrix ${ }^{\mathrm{a}}$.

\begin{tabular}{|c|c|c|c|c|c|c|c|}
\hline \multirow{2}{*}{ Variables } & \multicolumn{7}{|c|}{ Factor } \\
\hline & 1 & 2 & 3 & 4 & 5 & 6 & 7 \\
\hline EE3 & 1 & 2 & 3 & 4 & 5 & 6 & 7 \\
\hline EE5 & 0.892 & & & & & & \\
\hline EE4 & 0.808 & & & & & & \\
\hline EE2 & 0.899 & & & & & & \\
\hline ENT5 & 0.769 & & & & & & \\
\hline ENT4 & & 0.959 & & & & & \\
\hline ENT6 & & 0.811 & & & & & \\
\hline ATB4 & & 0.794 & & & & & \\
\hline ATB5 & & & 0.876 & & & & \\
\hline ATB3 & & & 0.793 & & & & \\
\hline $\mathrm{ENBR} 2$ & & & 0.754 & & & & \\
\hline ENBR3 & & & & 0.917 & & & \\
\hline ENBR 1 & & & & 0.902 & & & \\
\hline ENBR4 & & & & 0.787 & & & \\
\hline GPS2 & & & & 0.781 & & & \\
\hline GPS1 & & & & & 0.890 & & \\
\hline GPS3 & & & & & 0.841 & & \\
\hline GPS4 & & & & & 0.767 & & \\
\hline SE1 & & & & & 0.699 & & \\
\hline SE2 & & & & & & 0.816 & \\
\hline SE3 & & & & & & 0.919 & \\
\hline $\mathrm{SBN} 2$ & & & & & & 0.730 & \\
\hline SBN1 & & & & & & & 0.946 \\
\hline SBN3 & & & & & & & 0.759 \\
\hline
\end{tabular}

Note:

Extraction Method: Maximum likelihood.

Rotation Method: Promax with Kaiser Normalization

a.Rotation converged in 6 iterations.

Table 5. Model fit index.

\begin{tabular}{|c|c|c|c|c|c|c|c|c|}
\hline \multicolumn{9}{|c|}{ The Overall Goodness of Fit Model Criteria and Results } \\
\hline \multicolumn{3}{|c|}{ “Absolute” } & \multicolumn{3}{|c|}{ “Relative" } & \multicolumn{3}{|c|}{ "Parsimonious" } \\
\hline Fit Index & $\begin{array}{l}\text { Measurement } \\
\text { Criteria }\end{array}$ & Results & $\begin{array}{c}\text { Fit } \\
\text { Index }\end{array}$ & $\begin{array}{l}\text { Measurement } \\
\text { Criteria }\end{array}$ & Results & $\begin{array}{c}\text { Fit } \\
\text { Index }\end{array}$ & $\begin{array}{c}\text { Measurement } \\
\text { Criteria }\end{array}$ & Results \\
\hline Chi-square & $p>0.05$ & 0.000 & $\mathrm{CFI}$ & $>0.90$ & 0.906 & PCFI & $>0.50$ & 0.736 \\
\hline $\mathrm{CMIN} / \mathrm{DF}$ & $<5.0$ & 2.439 & IFI & $>0.90$ & 0.907 & PNFI & $>0.50$ & 0.704 \\
\hline GFI & $>0.90$ & 0.903 & & & & & & \\
\hline AGFI & $>0.80$ & 0.883 & & & & & & \\
\hline RMSEA & $<0.10$ & 0.070 & & & & & & \\
\hline
\end{tabular}

Source: Goodness of Fit Criteria Adapted from Meyers et al. (2016): Applied Multivariate Research: Design and Interpretation.

\section{Results}

The process of the data analysis for this current study began with the description of the respondent's profiles. The data was collected through a questionnaire distributed via an electronic google form. The respondents were 400 students of Chukwuemeka Odumegwu Ojukwu university students in Anambra State, Nigeria. Below is the respondent's profile information:
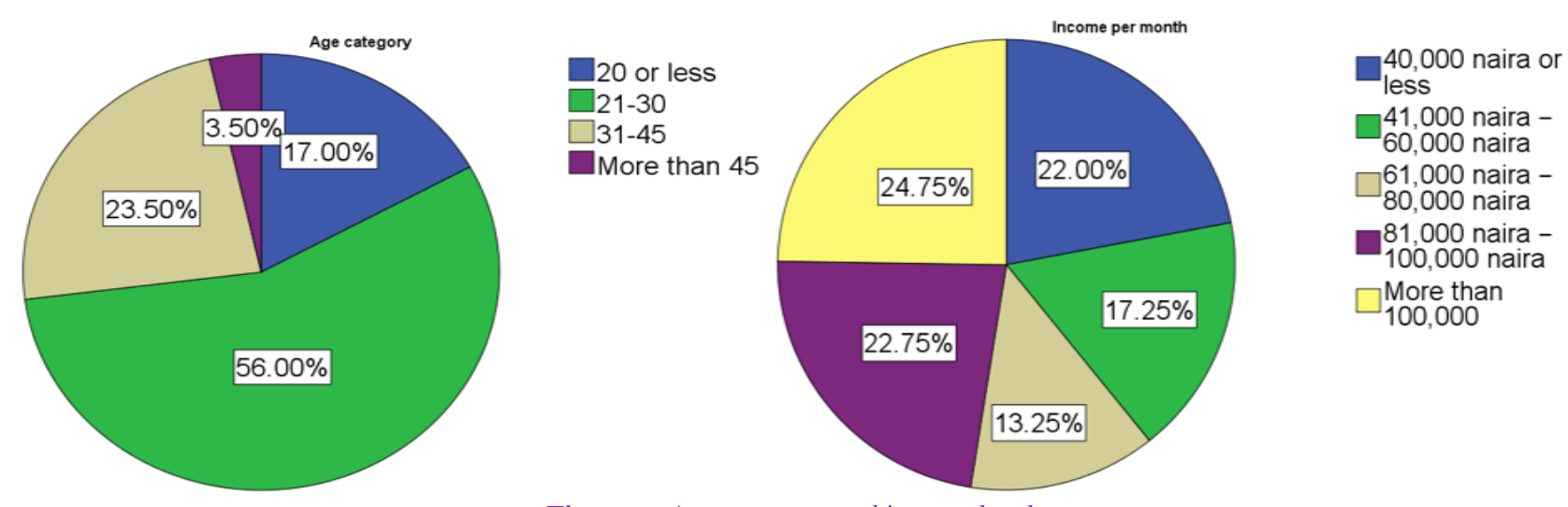

Figure 3. Age category and income level.

The respondent's age is ranged from 21-30 years (56\%), 31-45 years (23\%), and 20 or less years (17\%). The income level where fairly distributed with a slight majority of over 100,000 Naira (24\%) with the rest of the income levels (see Figure 3). Most of the respondents are still in their productive age so, they can engage in entrepreneurial activities in the society. The data also showed that most of the respondents have experience in doing business either as their own or working for others and they have taken some entrepreneurial courses previously (62\%). However, there are no huge difference between gender (Male $=51 \%$, Female $=49 \%$ ) respectively (see Figure 4 ). 

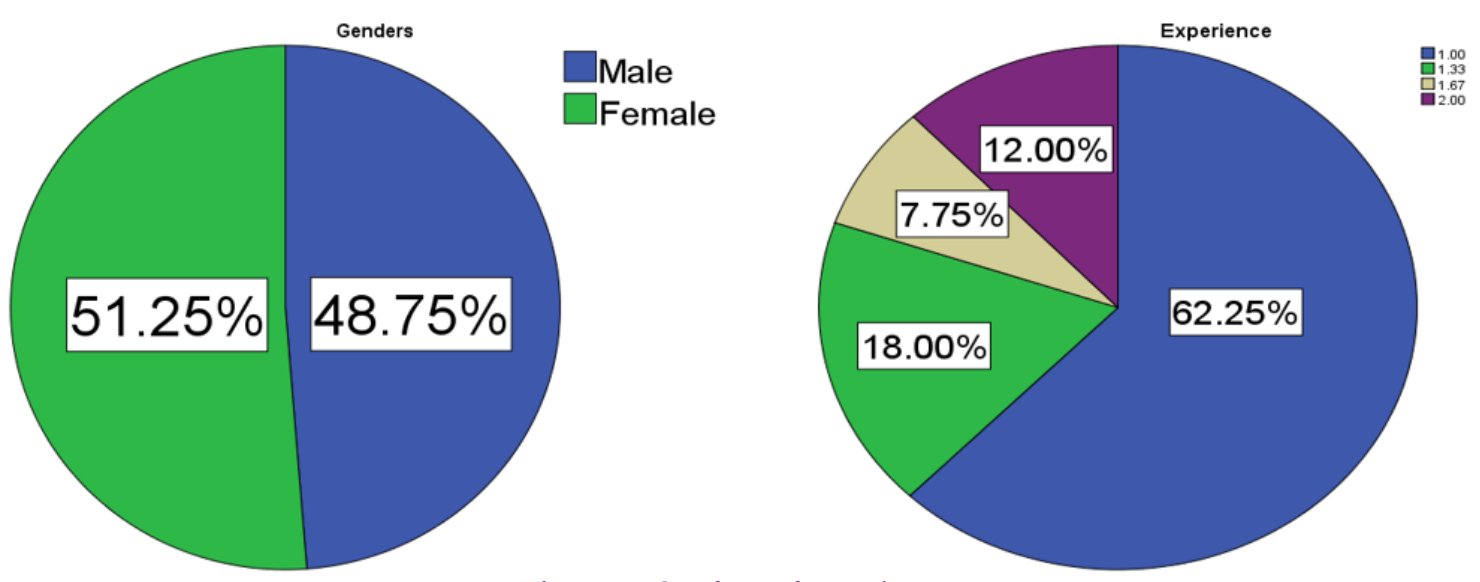

Figure 4. Gender and experience.

\subsection{Measurement and Structural Models Estimation}

AMOS Software version 23 was used to perform the structural equation modelling (SEM) for the data analysis. Before the structural model estimation, the correlation coefficient was observed between the variables. According to Hair, Anderson, Tatham, and William (1995), the presence of a correlation above 0.8-0.9 is a sign of multi-collinearity problem. In this research, there were no presence of a multi-collinearity. As depicted in Table 6, the correlation matrix results between the "independent and the dependent variables" ranged between 0.009 and 0.291 (see Table 6) at $99 \%$ significance level. Furthermore, the structural model estimation validates the relationship between the "dependent and the independent variables" of the research. The results showed that the independent variables explained approximately $22 \%$ of the variance of entrepreneurial intention (see Figure 5).

\begin{tabular}{l|c|c|c|c|c|c|c}
\hline Variables & $\begin{array}{c}\text { Self- } \\
\text { Efficacy }\end{array}$ & $\begin{array}{c}\text { Govt- } \\
\text { Support }\end{array}$ & $\begin{array}{c}\text { Env- } \\
\text { Barrier }\end{array}$ & $\begin{array}{c}\text { Ent- } \\
\text { Education }\end{array}$ & $\begin{array}{c}\text { Sub- } \\
\text { Norm }\end{array}$ & Attitude & Intention \\
\hline Self-Efficacy & 1 & & & & & & \\
\hline Govt-Support & $0.03^{* * *}$ & 1 & & & & & \\
\hline Env-Barrier & $0.07^{* * *}$ & $0.13^{* * *}$ & 1 & & & & \\
\hline Ent-Education & $0.127^{* * *}$ & $-0.039^{* * *}$ & $0.118^{* * *}$ & 1 & & & \\
\hline Sub-Norm & $0.176^{* * *}$ & $0.103^{* * *}$ & $-0.147^{* * *}$ & $0.083^{* * *}$ & 1 & & \\
\hline Attitude & $0.016^{* * *}$ & $-0.016^{* * *}$ & $-0.057^{* * *}$ & $0.148^{* * *}$ & $0.029^{* * *}$ & 1 & \\
\hline Intention & $0.265^{* * *}$ & $-0.102^{* * *}$ & $-0.009^{* * *}$ & $0.044^{* * *}$ & $0.186^{* * *}$ & $0.291^{* * *}$ & 1 \\
\hline Note: **** Correlation & was significant at the 0.01 level. & & & & 1 \\
\hline
\end{tabular}

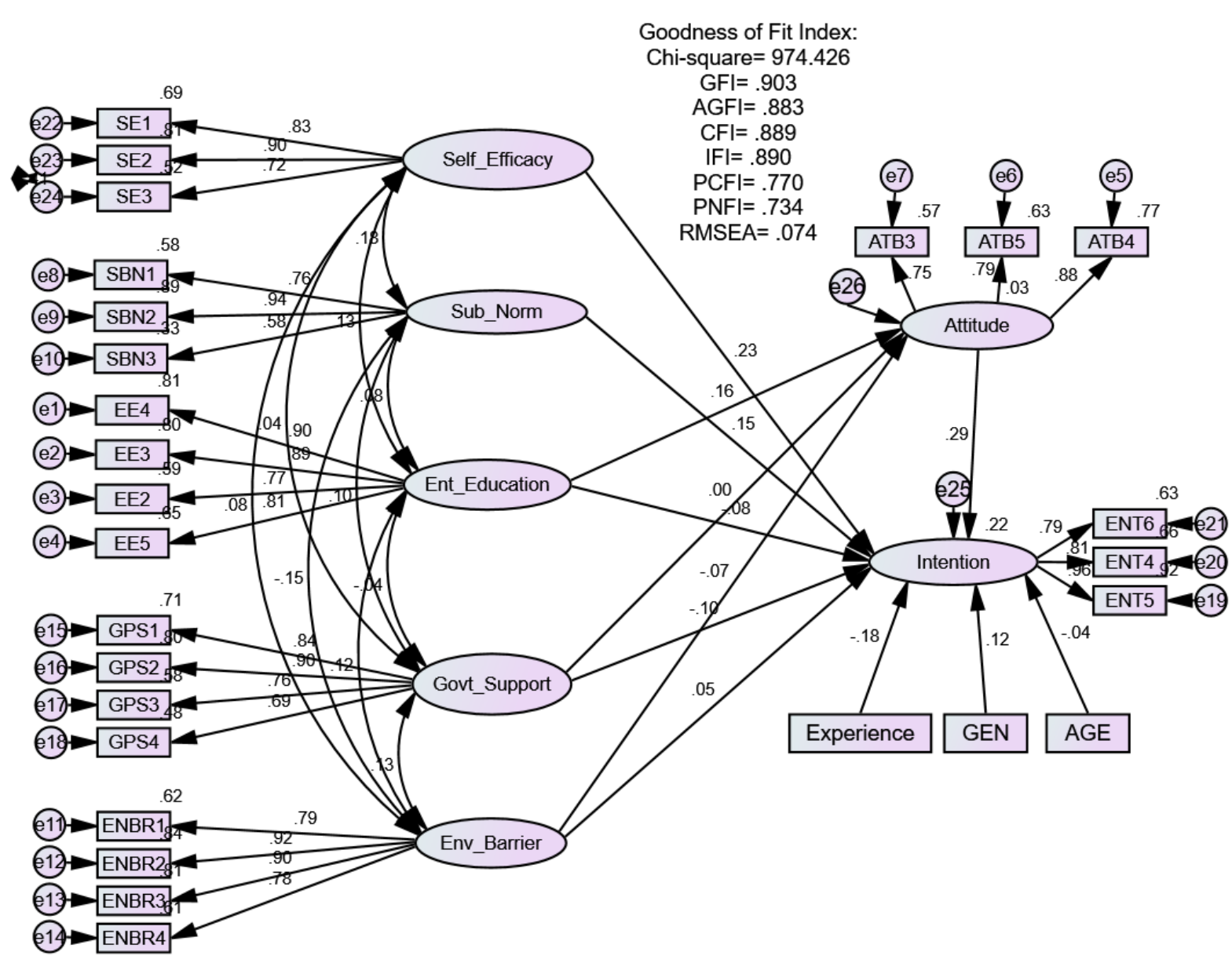

Figure 5. The path analysis model.

Note: "Goodness-of-fit statistics": "Relative chi-square" = 2.980; GFI=0.903, AGFI=0.883, CFI=0.906, $\mathrm{IFI}=0.907, \mathrm{PCFI}=0.736, \mathrm{PNFI}=0.704, \mathrm{RMSEA}=$ 0.070 . 
From the findings, five hypotheses have a significant relationship and was accepted at $\mathrm{p}$ value $<0.100, * * \mathrm{p}<$ $0.010,{ }^{*} * * \mathrm{p}<0.001$ two-tailed respectively (see Table 7 ).

Table 7. Results.

\begin{tabular}{|c|c|c|c|c|c|}
\hline \multicolumn{3}{|c|}{ Hypothesized relationship } & $\begin{array}{l}\text { "Standardized } \\
\text { Estimates" }(\boldsymbol{\beta})\end{array}$ & Significance & Findings \\
\hline $\mathrm{H}_{1}$ : Attitude & $\longrightarrow$ & Intention & 0.290 & **** & Accepted \\
\hline $\mathrm{H}_{2}:$ Self-Efficacy & $\longrightarrow$ & Intention & 0.234 & **** & Accepted \\
\hline $\mathrm{H}_{3}:$ Subject Norm & $\longrightarrow$ & Intention & 0.154 & $0.011 * *$ & Accepted \\
\hline $\mathrm{H}_{4}$ : Entrepreneurial Education & $\longrightarrow$ & Attitude & 0.160 & $0.007 * * *$ & Accepted \\
\hline $\mathrm{H}_{5}$ : Entrepreneurial Education & $\longrightarrow$ & Intention & -0.05 & 0.130 & Rejected \\
\hline $\mathrm{H}_{6}$ : Govt. Support Policy & $\longrightarrow$ & Attitude & 0.007 & 0.872 & Rejected \\
\hline $\mathrm{H}_{7}$ : Govt. Support Policy & $\longrightarrow$ & Intention & -0.130 & 0.0734 & Accepted \\
\hline $\mathrm{H}_{8}$ : Environmental Barrier & $\longrightarrow$ & Attitude & -0.074 & 0.184 & Rejected \\
\hline $\mathrm{H}_{9}$ : Environmental Barrier & $\longrightarrow$ & Intention & 0.031 & 0.341 & Rejected \\
\hline
\end{tabular}

Table 8. Control variables.

\begin{tabular}{l|c|c|c}
\hline Hypothesized relationship & Standardized Estimates $(\beta)$ & Significance & Findings \\
\hline Experience $\longrightarrow$ Intention & -0.180 & $* * *$ & Accepted \\
\hline Gender $\longrightarrow$ Intention & 0.120 & $0.024 * *$ & Accepted \\
\hline Age $\longrightarrow$ Intention & -0.044 & 0.379 & Rejected \\
\hline Note: Significance
\end{tabular}

Table 8 illustrates the control variables effects on the dependent variable intention. The result showed that experience and gender have a significant impact on intention, however, age was not statistically significant on students' entrepreneurial intention.

\section{Discussion}

The purpose of this research was to investigate the motivating factors of youth's interest in pursuing a career as entrepreneurs in Anambra State, Nigeria. Drawing on the TPB as personality attributes and the perception of entrepreneurial education \& government support as opportunity or barrier to propose a model. To address this purpose, a sample of 400 respondents from Chukwuemeka Odumegwu Ojukwu university students were drawn to test the hypotheses. The results concurred with previous studies on the impact of entrepreneurial intention, nonetheless there are some differences as well. From the data analysis, $\mathrm{H}_{1}$ was supported and accepted $(\beta=0.290$; $\mathrm{p}<0.001$ ), this result conformed with Lopez et al. (2021); Seth (2020) findings that attitude towards behavior has significant impact on intention. This signifies those students with positive attitude will likely be creative in finding business opportunities and he or she makes a better decision to become entrepreneurs as they are more resilient in overcoming obstacles which boosts their chances of success in any business endeavors. Moreover, as expected, the result of $\mathrm{H}_{2}$ was supported and sustained ( $\left.\beta=0.234 ; \mathrm{p}<0.001\right)$. This finding aligned with Garaika et al. (2019); Liu et al. (2019) which found that "self-efficacy has a significant influence on entrepreneurial intention". This implies that those aspiring young entrepreneurs who have confidence in their ability and intellectual levels tends to have strong motivation to engage in entrepreneurship. The results also demonstrated empirically how social pressure perceived by students from their reference group like influential people, family members or other role models have a significant impact on students' entrepreneurial interest, thus $\mathrm{H}_{3}$ was supported $(\beta=0.154 ; \mathrm{p}<0.05)$. This result conformed with Karimi et al. (2016) and Seth (2020) that found statistical positive relationship between subjective norms and intention however, this findings are still inconsistent stated (Lopez et al., 2021) as the authors found a negative association between subjective norms and intention.

Furthermore, the result of $\mathrm{H}_{4}$ was significant and accepted $(\beta=0.160 ; \mathrm{p}<0.001)$, however, $\mathrm{H}_{5}$ was not supported hence, was rejected $(\beta=-0.054 ; \mathrm{p}<0.05)$. According to Landry et al. (2006), the association between the entrepreneurial training and attitude on students intention to become entrepreneurs are still conflicting, for instance, Nagarathanam, Buang, and Rahman (2017) found a statistical significance that entrepreneurial education can increase the positive attitude of students to become entrepreneurs and consequently increasing their level of entrepreneurial intention, however, Karimi et al. (2016) found no evidence between entrepreneurial education and intention. Furthermore, Seth (2020) noted that "entrepreneurial education have a positive relationship with students' attitudes toward behavior which invariably increase their entrepreneurial intention". In the context of Nigeria, this research found that entrepreneurship education and or training influences attitude but not necessarily the intention to pursue entrepreneur as a career. The reason may be because, most of the youths go through apprenticeship and acquire a real-life business experience that are not learned in academic institutions. Additionally, with respect to government policy support or barrier on attitude and intention, $\mathrm{H}_{6}$ was not significant and was rejected $(\beta=-0.007 ; \mathrm{p}<0.05)$, however, $\mathrm{H}_{7}$ has a significant negative relationship and was not rejected $(\beta=-0.130 ; \mathrm{p}<0.10)$. This signifies that, government policy support influences entrepreneurial intention. This findings supported the analysis of Udu (2015) regarding the impact of macroeconomic policy and its impact on small and new businesses. The author posited that less than $5 \%$ of new small businesses survive beyond their first five years of existence due to the difficulties in getting access to funding and other support from the government in Nigeria. Government support policies has a direct impact on the potential business source of funds (loans or credit) from the government and commercial banks, as well as adequate, supportive, and favorable macroeconomic business environment. In addition, the result of this hypothesis did not support the findings of Schwarz, Wdowiak, Almer-Jarz, and Breitenecker (2009b) that found government environmental support to be statistically insignificant with intention. However, the results of $\mathrm{H}_{8} \& \mathrm{H}_{9}$ was not supported $(\beta=-0.074 \& 0.031 ; \mathrm{p}<0.05)$. This findings supported the findings of Schwarz et al. $(2009 \mathrm{~b})$ that found no statistical significance between barrier and intention. Hence, these results might be partially conflicting with the 
findings of environmental support or barrier impact on students' entrepreneurial intention from other countries due to differences in context and environment conditions. Based on Nigeria context, the reason might be because, barrier as competition is unavoidable in business which does not influence intention. Similarly, lack of unqualified consultants and insufficient market information have no impact on intention because, youths learn entrepreneurship through apprenticeship or family members in Nigeria context and culture.

The result of the control variables effects on intention are as follows: entrepreneurial experience and gender has an impact on interest to become entrepreneurs $(\beta=-0.180 \& 0.124 ; p<0.001)$. The result supported the findings of Zhang et al. (2014) regarding the impact of entrepreneurial experience and Do Paço et al. (2015) influence of gender on student's decision to become entrepreneurs. In support of that, Landry et al. (2006) noted that the more experience an individual has, the more the probability that he or she can detect the right business opportunities to exploit for new venture creation, however, in the case of Nigeria, there is a statistical negative association between youths entrepreneurial experience and intention. The reason might be because, students with entrepreneurial experience tends to understand the reality of the unfavorable macroeconomic environment of doing business in Nigeria, so, this would have an impact on their intention to open new business, likewise gender. However, the result of age was rejected $(\beta=-0.044 ; p<0.05)$ hence, age have no significant impact on youth's entrepreneurship interest in Anambra State, Nigeria.

\section{Conclusion}

This research explored the determinants of "entrepreneurial intention among university students" by developing a conceptual framework comprising personality traits and environmental factors which includes general personality attributes from TPB and the perception of environmental support or barrier. Pertaining the personality attributes, this study concludes that attitude, self-efficacy, and subject norm have been confirmed as an important factor in predicting youth's entrepreneurial interest. Additionally, entrepreneurial education has significant impact on attitude towards behavior but not necessarily leading to intention to engage in entrepreneurship process. On the other hand, regarding the environmental support or barrier, this study found government support policy as having significant effects on students' interest in entrepreneurs. Factors of environmental barrier like lack of access to funds or redtape processes associated with new venture creation have no statistical significance on youths' interest to become entrepreneurial in Anambra State of Nigeria. The results on environmental conditions on students' intention to become entrepreneurs are rather contrasting in the literature and in different cultural contexts. Notably, this study did not evaluate the environmental conditions directly but relied on students' subjective judgments for the result analysis. Furthermore, on the control variable, this study detected a significant impact of experience and gender on entrepreneurial intention like previous research, however, no significance was detected on age level of student's impact on their interest to become entrepreneur.

\section{Managerial Implication and Recommendations}

This study provided both academic and practical suggestions for universities and stakeholder of the society. From the academic and theoretical implications, first, this study contributes by integrating the TPB as personality attributes and environmental condition variables and its antecedents on entrepreneurial intention. Secondly, this study validated the scales used to measure the TPB antecedents and entrepreneurial intention in a different cultural context of non-Western countries such as Anambra State, Nigeria and provided further supporting evidence in predicting entrepreneurial intention. The integration of these variables for this study's conceptual model and the validation of the scales used in this study will offer more instrument that allows researchers to propose new models and to prove their relationships.

Practically, the result of this research provided a "valuable information" for government effective policies formulations and implementation, for the banks, the universities, and other stakeholder. Firstly, this study confirmed the significance of TPB and government support by strengthening the antecedents of entrepreneurial intention. There "is a positive relationship between personality attribute of TPB and environmental government support on intention". This implies that university students will develop more interest in entrepreneurial activities if they have more support system like availability of funds. As the results indicated regarding personality attributes, youths are willing to engage in entrepreneurship as a career option if there are tools and support mechanisms to improve their perception about entrepreneurship in Nigeria. A conducive external macroeconomic environment to ease in youths' decision to become entrepreneurs is vital. On that note, the universities in Nigeria should provide support through different channels including the provision of essential tools to facilitates students learning and training as well as inviting successful entrepreneurs (role models) as extracurricular activities to motivate students through interactions as the result proved a statistical significance of the impact of role models in enhancing practical entrepreneurial skills. Secondly, this study also contributed practically by providing a valuable information about the importance of government support, which provides an avenue for youths with the visions and aspirations but lacks the financial capacity to act in pursuing their dreams. This is a vicious cycle, from the introduction section above, the actions of the government are evidently inadequate with high unemployment rates among the youths in Nigeria which has also been confirmed by the findings of this research. Therefore, the government and other important stakeholders need to re-strategize and make an urgent U-turn in their entrepreneurship policies to be more supportive and inclusive. This will engage the youths in entrepreneurship and motivate them to be independent which will nurture "sustainable economic development" in the Anambra state, Nigeria. The findings of this research can aid the government and other stakeholders like universities in developing agendas that promote youths' interest in entrepreneurship activities in the country. This finding can also support the commercial banks in creating a more funding policies for youth's entrepreneurship in the state. Finally, although the entrepreneurial education was detected to be insignificant in this study, there is no doubt about the importance of the need to improve education system in the country as indicated by low HDI. The youths are the pillar and the future of every nation, and for inclusivity and long term sustainable economic growth, environmental and social development, education plays a vital role in making them self-reliance by providing them with entrepreneurial education to learn and obtain the modern knowledge and tools to stay hungry for success and aspirations. 


\section{Limitation and Future Research}

The result of this research provided insightful suggestion which are beneficial in understanding students intention to become entrepreneurs and provided a considerable information for both theory and practical implication. Nevertheless, this study has some limitations. Firstly, generalization of the findings of this study is difficult because of context and other environmental conditions that differs from country to country. Secondly, this is a case study of only one university in Anambra State, Nigeria, therefore, a sampling error might create some bias in the generalization of the results. Thirdly, this research applied "quantitative method with a proposed conceptual model" with only selected general attitudes and environmental conditions in the model. There are other notable factors that significantly relates with entrepreneurial intention omitted from this research model.

To encourage students' intention to become businesspersons, this current study provides several recommendations. The results indicated that personality traits strongly influence entrepreneurial intention however, entrepreneurial education and other external conditions were not significant. The reasons for unsupported result between entrepreneurial education on intention is unclear, so, further studies are needed to establish concrete results. Additionally, students' decision to become entrepreneurs as a career choice is a complex process. A lot of previous studies on "entrepreneurial intention" were based on individual personalities with little attention on the impact of the external environments that influence students' interest in entrepreneurship, therefore, further studies can explore environmental factors as well as the personality factors in the prediction on intention. It is also crucial to explore beyond intention to actual entrepreneurship.

\section{References}

Abdullahi, D., Renukappa, S., Suresh, S., \& Oloke, D. (2021). Barriers for implementing solar energy initiatives in Nigeria: An empirical study. Smart and Sustainable Built Environment.Available at: https://doi.org/10.1108/SASBE-06-2020-0094.

Acs, Z. J., Szerb, L., \& Autio, E. (2017). Global entrepreneurship and development index 2011 (Vol. 49): Springer.

Ajah, S. N. (2019). Solar energy: A source of renewable energy and a disruptive innovation creating business opportunities in Nigeria. Human Behavior, Development and Society, 20(3), 85-94.

Ajzen, I. (2002). Perceived behavioral control, self-efficacy, locus of control, and the theory of planned behavior 1. Journal of Applied Social Psychology, 32(4), 665-683.Available at: https://doi.org/10.1111/j.1559-1816.2002.tbo0236.x.

Ajzen, I., Fishbein, M., Lohmann, S., \& Albarracín, D. (2018). The influence of attitudes on behavior. The handbook of attitudes, 197-255.

Ajzen, I. (2011). The theory of planned behaviour: Reactions and reflections. Psychology \& Health, 26(9), 1113-1127.Available at: https://doi.org/10.1080/08870446.2011.613995.

Alemu, Z. G. (2019). Working paper 327-poverty in Nigeria: A multidimensional approach (No. 2453).

Apostolopoulos, N., Al-Dajani, H., Holt, D., Jones, P., \& Newbery, R. (2018). Entrepreneurship and the sustainable development goals: Emerald Publishing Limited.

Bandura, A. (1977). Self-efficacy: Toward a unifying theory of behavioral change. Psychological Revierw, 84(2), 191-215.Available at: https://doi.org/10.1037/0033-295x.84.2.191.

Barbosa, S. D., Gerhardt, M. W., \& Kickul, J. R. (2007). The role of cognitive style and risk preference on entrepreneurial self-efficacy and entrepreneurial intentions. Journal of Leadership \& Organizational Studies, 13(4), 86-104.Available at: https://doi.org/10.1177/10717919070130041001.

Barry, M. (1998). Who becomes an entrepreneur? , BA Business Management Dissertation, Leeds Business School, Leeds.

Baumol, W. J., Litan, R. E., Schramm, C. J., \& Strom, R. J. (2011). Innovative entrepreneurship and policy: Toward initiation and preservation of growth. In The Economics of Small Businesses (pp. 3-23): Springer.

Bell, E., Bryman, A., \& Harley, B. (2018). Business research methods. USA: Oxford University Press.

Chen, G., Gully, S. M., \& Eden, D. (2001). Validation of a new general self-efficacy scale. Organizational Research Methods, 4(1), 62-83.

Do Paço, A., Ferreira, J. M., Raposo, M., Rodrigues, R. G., \& Dinis, A. (2015). Entrepreneurial intentions: Is education enough? International Entrepreneurship and Management Journal, 11(1), 57-75.

Drucker, P. (2014). Innovation and entrepreneurship: Routledge.

Ebitu, E. T., Glory, B., \& Alfred, U. J. (2016). An appraisal of Nigeria's micro, small and medium enterprises (MSMEs): Growth, challenges and prospects. British Journal of Marketing Studies, 4(5), $21-36$

Economic, U. N. D. O., \& Affairs, S. (2018). World youth report: Youth and the 2030 agenda for sustainable development: United Nations Publications.

Fellnhofer, K., \& Mueller, S. (2018). "I want to be like you!": The influence of role models on entrepreneurial intention. Journal of Enterprising Culture, 26(02), 113-153.

Fragoso, R., Rocha-Junior, W., \& Xavier, A. (2020). Determinant factors of entrepreneurial intention among university students in Brazil and Portugal. Journal of Small Business \& Entrepreneurship, 32(1), 33-57.Available at: https://doi.org/10.1080/08276331.2018.1551459.

Garaika, G., Margahana, H. M., \& Negara, S. T. (2019). Self efficacy, self personality and self confidence on entrepreneurial intention: Study on young enterprises. Journal of Entrepreneurship Education, 22(1), 1-12.

García-Rodríguez, F. J., Gil-Soto, E., Ruiz-Rosa, I., \& Sene, P. M. (2015). Entrepreneurial intentions in diverse development contexts: A crosscultural comparison between Senegal and Spain. International Entrepreneurship and Management Journal, 11(3), 511-527.Available at: https://doi.org/10.1007/s11365-013-0291-2.

Gaskin, J., \& Lim, J. (2016). Master validity tool. AMOS Plugin In: Gaskination's StatWiki.

Gist, M. E. (1987). Self-efficacy: Implications for organizational behavior and human resource management. Academy of Management Reviere, 12(3), 472-485.Available at: https://doi.org/10.5465/amr.1987.4306562.

Hai, M. (202 1). Soocial acceptance of solar energy as intention, willingness, and readiness.

Hair, J. J. F., Anderson, R. E., Tatham, R. L., \& William, C. (1995). Multivariate data analysis with readings. New Jersy: Prentice Hall.

Hair, J., J. F., Hult, G. T. M., Ringle, C. M., \& Sarstedt, M. (2021). A primer on partial least squares structural equation modeling (PLS-SEM): Sage Publications.

Hu, L.-t., \& Bentler, P. M. (1999). Cutoff criteria for fit indexes in covariance structure analysis: Conventional criteria versus new alternatives. Structural Equation Modeling: A Multidisciplinary Journal, 6(1), 1-55.

Hynes, B., \& Richardson, I. (2007). Entrepreneurship education: A mechanism for engaging and exchanging with the small business sector. Education Training, 49(8-9), 732-744.

Igwe, C., Adebayo, M., Olakanmi, O., Ogbonna, I., \& Aina, O. (2013). Promoting wealth and job creation in Nigeria review of the role of entrepreneurship. Journal of Sustainable Development Studies, 3(1), 80-100.

Israel, G. D. (1992). Determining sample size (Fact sheet PEOD-6) (pp. 1-5). Gainesville, FL: University of Florida.

Jobs, S. (2009). Steve jobs quotes. Famous Quotes and Quotations at Brainy Quote.

Karimi, S., Biemans, H. J., Lans, T., Chizari, M., \& Mulder, M. (2016). The impact of entrepreneurship education: A study of Iranian students' entrepreneurial intentions and opportunity identification. Journal of Small Business Management, 54.(1), 187-209.

Koksal, S., Namal, N., Vehid, S., \& Yurtsever, E. (2005). Knowledge and attitude towards HIV/AIDS among Turkish students. Infectious Diseases Journal of Pakistan, 14(4), 118-123.

Kressel, H., \& Lento, T. V. (2012). Entrepreneurship in the global economy: Engine for economic growth. Cambridge: Cambridge University Press.

Kristiansen, S., \& Indarti, N. (2004). Entrepreneurial intention among Indonesian and Norwegian students. Journal of Enterprising Culture, 12(01), 55-78.Available at: https://doi.org/10.1142/s02 1849580400004x.

Krueger Jr, N. F., Reilly, M. D., \& Carsrud, A. L. (2000). Competing models of entrepreneurial intentions. Journal of Business Venturing, $15(5-$ 6), 41 1-432.Available at: https://doi.org/10.1016/s0883-9026(98)00033-0. 
Kuratko, D. F. (2016). Entrepreneurship: Theory, process, and practice: Cengage Learning.

Landry, R., Amara, N., \& Rherrad, I. (2006). Why are some university researchers more likely to create spin-offs than others? Evidence from Canadian universities. Research Policy, 35(10), 1599-1615.Available at: https://doi.org/10.1016/j.respol.2006.09.020.

Latha, K. L., \& Murthy, B. (2009). The motives of small scale entrepreneurs: An exploratory study. South Asian Journal of Management, 16(2), 91-108.

Lawler, J., \& Joseph, A. (2012). Cloud computing as a core discipline in a technology entrepreneurship program. Information Systems Education Journal, 1O(3), 55-66.

Li, J., Wu, S., \& Wu, L. (2008). The impact of higher education on entrepreneurial intentions of university students in China. Journal of Small Business and Enterprise Development.

Liu, X., Lin, C., Zhao, G., \& Zhao, D. (2019). Research on the effects of entrepreneurial education and entrepreneurial self-efficacy on college students' entrepreneurial intention. Frontiers in Psychology, 10, 869.Available at: https://doi.org/10.3389/fpsyg.2019.00869.

Lopez, T., Alvarez, C., Martins, I., Perez, J. P., \& Románn-Calderón, J. P. (2021). Students' perception of learning from entrepreneurship education programs and entrepreneurial intention in Latin America. Academy Latin American Journal of Administration, 34(3), 419444.Available at: https://doi.org/10.1108/arla-07-2020-0169.

Lüthje, C., \& Franke, N. (2003). The 'making'of an entrepreneur: Testing a model of entrepreneurial intent among engineering students at MIT. REd Management, 33(2), 135-147.Available at: https://doi.org/10.1111/1467-9310.00288.

Mahalanobis, P. C. (1936). On the generalized distance in statistics. National Institute of Science of India, 12, 49-55.

Martins, I., \& Perez, J. P. (2020). Testing mediating effects of individual entrepreneurial orientation on the relation between close environmental factors and entrepreneurial intention. International Journal of Entrepreneurial Behaviour and Research, 26(4), 771791.Available at: https://doi.org/10.1108/ijebr-08-2019-0505.

McDonald, S., Gan, B. C., Fraser, S. S., Oke, A., \& Anderson, A. R. (2015). A review of research methods in entrepreneurship $1985-2013$. International Journal of Entrepreneurial Behaviour \& Research, 21(3), 291-315.

Meyers, L. S., Gamst, G., \& Guarino, A. J. (2016). Applied multivariate research: Design and interpretation: Sage Publications.

Miranda, F. J., Chamorro-Mera, A., Rubio, S., \& Pérez-Mayo, J. (2017). Academic entrepreneurial intention: the role of gender. International Journal of Gender and Entrepreneurship.

Nagarathanam, R., Buang, N. A., \& Rahman, R. S. A. R. A. (2017). The Entrepreneurial behavior of malaysian indian undergraduates in entrepreneurship career choice intention. Paper presented at the ASCENT International Conference Proceeding - Accounting and Business Management.

Oghojafor, B., Kuye, O., Sulaimon, A., \& Okonji, P. (2009). Empowering Nigerian youths for national economic development: The role of entrepreneurship education. Journal of Research in National Development, 7(2), 9-17.Available at: https://doi.org/10.4314/jorind.v7i2.50945.

Padilla-Angulo, L. (2019). Student associations and entrepreneurial intentions. Studies in Higher Education, 44(1), 45-58.Available at: https://doi.org/10.1080/03075079.2017.1336215.

Petrin, T. (1994). Entrepreneurship and supporting institutions: An analytical approach. Seventh FAO/REU International Rural Development Summer School. Herrsching, Germany: FAO.

Rashid, L. (2019). Entrepreneurship education and sustainable development goals: A literature review and a closer look at fragile states and technology-enabled approaches. Sustainability, 11(19), 5343.Available at: https://doi.org/10.3390/su11 195343.

Saunders, M., Lewis, P., \& Thornhill, A. (2016). Research methods for business students (Seventh). Nueva York: Pearson Education.

Schumpeter, J. A. (2017). The theory of economic development: An inquiry into profits, capita i, credit, interest, and the business cycle: Routledge.

Schwarz, E. J., Wdowiak, M. A., Almer-Jarz, D. A., \& Breitenecker, R. J. (2009a). The effects of attitudes and perceived environment conditions on students' entrepreneurial intent: An Austrian perspective. Education Training, 51(4), 272-291.

Schwarz, E. J., Wdowiak, M. A., Almer-Jarz, D. A., \& Breitenecker, R. J. (2009b). The effects of attitudes and perceived environment conditions on students' entrepreneurial intent: An Austrian perspective. Education Training, 51(4), 272-291.

Seth, K. P. (2020). The impact of entrepreneurship education on entrepreneurial intention: An empirical study of entrepreneurship education's four key characteristics. London: Brunel University.

Shane, S. A. (2007). Economic development through entrepreneurship: Government, university and business linkages: Edward Elgar Publishing.

Shaver, K. G. (2003). The social psychology of entrepreneurial behaviour. In Handbook of entrepreneurship research (pp. 331-357). Boston, MA: Springer.

Solesvik, M. Z. (2013). Entrepreneurial motivations and intentions: Investigating the role of education major. Education $\Xi$ Training, 55(3), 253-271.Available at: https://doi.org/10.1108/00400911311309314.

Udu, A. (2015). Apprenticeship orientation and performance of microbusinesses in Ebonyi State, Nigeria. European Journal of Biology and Medical Science Research, 3(6), 1-11.

Vesalainen, J., \& Pihkala, T. (1999). Motivation structure and entrepreneurial intentions. Frontiers of Entrepreneurship Research, $19,73-87$.

Vohora, A., Wright, M., \& Lockett, A. (2004). Critical junctures in the development of university high-tech spinout companies. Research Policy, 33(1), 147-175.Available at: https://doi.org/10.1016/s0048-7333(03)00107-0.

Zhang, Y., Duysters, G., \& Cloodt, M. (2014). The role of entrepreneurship education as a predictor of university students' entrepreneurial intention. International Entrepreneurship and Management Journal, 1O(3), 623-641.

Zhao, H., Seibert, S. E., \& Hills, G. E. (2005). The mediating role of self-efficacy in the development of entrepreneurial intentions. Journal of Applied Psychology, 90(6), 1265-1272.Available at: https://doi.org/10.1037/002 1-9010.90.6.1265.

Citation: Simon Nnaemeka Ajah (2022). Investigating the Motivating Factors of Youths-Students Interest to Become Entrepreneurs: A Case of Anambra State, Nigeria. Asian Business Research Journal, 7: 1-13.

History:
Received: 28 December 2021

Received: 28 December 2021

Revised: 31 January 2022

Accepted: 15 February 2022

Published: 23 February 2022
Licensed: This work is licensed under a Creative Commons

Attribution 4.0 License (cc) E

Publisher: Eastern Centre of Science and Education
Funding: This study received no specific financial support.

Competing Interests: The author declares that there are no conflicts of interests regarding the publication of this paper.

Transparency: The author confirms that the manuscript is an honest, accurate, and transparent account of the study; that no vital features of the study have been omitted; and that any discrepancies from the study as planned have been explained.

Ethical: This study followed all ethical practices during writing.

Eastern Centre of Science and Education is not responsible or answerable for any loss, damage or liability, etc. caused in relation to/arising out of the use of the content. Any queries should be directed to the corresponding author of the article. 